\title{
UŻYTECZNOŚĆ KONCEPCJI PRZYPADKU GRZEGORZA BUGAJAKA W NAUKACH PRZYRODNICZYCH
}

\begin{abstract}
Streszczenie. Rzeczywistość przyrodnicza poznawana jest dzięki metodom empirycznym. Jej tajemnice odkrywane są w dużym zakresie dzięki rozwojowi ich metodologii. Formułowane są hipotezy i tworzone teorie wyjaśniające odkrywane zjawiska. Jednakże w tym uporządkowanym świecie pojawiają się i takie zdarzenia, których wystąpienie ma charakter przypadkowy. Z tej racji zostanie zastosowana filozoficzna koncepcja przypadku wypracowana przez Grzegorza Bugajaka i przewidziana przez niego do analizy treści teorii naukowych oraz klasyfikacji zdarzeń przypadkowych. Zostanie ukazana użyteczność tej koncepcji w obszarze ochrony środowiska. W tym celu na początku zaprezentowana zostanie treść propozycji Bugajaka, a następnie omówione będą okoliczności pojawiania się w przyrodzie zjawisk przypadkowych, rodzących dylematy poznawcze u przyrodników. Podjęte analizy zostaną zilustrowane konkretnymi przykładami. W rezultacie wskazane zostaną te sposoby interpretacji przypadku z koncepcji Bugajaka, które mogą okazać się przydatne w pracach ekologów.
\end{abstract}

Słowa kluczowe: Grzegorz Bugajak; przypadek; przyroda; dylemat poznawczy; ochrona środowiska

1. Wprowadzenie. 2. Pojęcie przypadku w kontekście teorii naukowych. 3. Przypadek a nauki przyrodnicze. 4. Dylemat poznawczy jako skutek zdarzeń przypadkowych. 5. Zakończenie.

\section{WPROWADZENIE}

Przyrodnicy w swoich badaniach poszukują wyjaśnień i tworzą opisy zjawisk, zachodzących w przyrodzie. Zjawiska te zazwyczaj sterowane są jakimś rodzajem informacji. I tak, procesy noszące znamiona życia kierowane są informacją biologiczną. Oznacza to, że otaczająca nas przyroda jest uporządkowana według jakichś kryteriów. Jednakże przyrodnicy-praktycy napotykają w swoich badaniach na zjawiska wymykające się spod oczekiwanych reguł uporządkowania. 
Najczęściej takie nieprzewidywalne zjawiska określane są jako przypadkowe. Zakres zjawisk przypadkowych poszerza się w miarę rozwoju nauki, odkrywania coraz to nowych obszarów badań, stawiania kolejnych hipotez i formułowania teorii. Ujawniane są wciąż nowe zjawiska, które zaskakują, nazywane „przypadkowymi”. W związku z tym coraz więcej tych „przypadkowych” zdarzeń wymaga wyjaśnienia. Warto od razu zaznaczyć, że ekolodzy, podejmując decyzje o swoim działaniu, kierują się zwykle ustalonym celem swojej aktywności. $Z$ tego powodu podejmowane są dyskusje nad istotą przypadku. Są one ważne, gdyż zdarzają się wypowiedzi potoczne, w których wybrzmiewa przekonanie o utożsamianiu zjawiska przypadkowego z cudownym. Szczególnie nasilają się one wobec narastającego zainteresowania relacjami zachodzącymi między nauką a religią̧ ${ }^{1}$.

Inspiracje do weryfikacji takich tez można znaleźć między innymi w encyklice Papieża Jana Pawła II Fides et Ratio o relacjach między wiarą a rozumem. Czytamy tam między innymi: „Raz jeszcze zostaje tu potwierdzona podstawowa harmonia poznania filozoficznego i poznania wiary: wiara domaga się, aby jej przedmiot został poznany przy pomocy rozumu; rozum, osiągając szczyt swoich poszukiwań, uznaje, jak konieczne jest to, co ukazuje mu wiara"2. I dalej: „Mimo to jednak obecna relacja między wiarą a rozumem domaga się wysiłku wnikliwego rozeznania, ponieważ zarówno rozum, jak i wiara zostały zubożone i osłabione w swych wzajemnych odniesieniach. Rozum, pozbawiony wsparcia ze strony Objawienia, podążał bocznymi drogami, na których istniało ryzyko zagubienia jego ostatecznego celu. Wiara, pozbawiona oparcia w rozumie, skupiła się bardziej na uczuciach i przeżyciach, co stwarza zagrożenie, że przestanie być propozycją uniwersalną. Złudne jest mniemanie,

1 G. Bugajak, „Rozum a wiara” - problem separacji dyscyplin, Studia Philosophiae Christianae 43(2007)2, 132-148; Tenże, Początek świata w nauce i religii. W poszukiwaniu możliwości syntezy, Studia Philosophiae Christianae 32(1996)2, 135-147; M. Heller, Bóg i geometria. Gdy przestrzeń była Bogiem, Kraków 2016.

2 Jan Paweł II, Fides et ratio, p. 42. 
że wiara może silniej oddziaływać na słaby rozum; przeciwnie, jest wówczas narażona na poważne niebezpieczeństwo, może bowiem zostać sprowadzona do poziomu mitu lub przesądu. Analogicznie, gdy rozum nie ma do czynienia z dojrzałą wiarą, brakuje mu bodźca, który kazałby skupić uwagę na specyfice i głębi bytu"3.

W niniejszym tekście chcemy, idąc za wskazaniem wspomnianej encykliki, „poruszyć rozum” i rozważyć możliwość odróżnienia przypadku od cudu, a następnie skorzystać z propozycji Grzegorza Bugajaka, aby podjąć próbę zastosowania jego koncepcji w naukach przyrodniczych, a przede wszystkim w praktyce ochrony przyrody.

\section{POJĘCIE PRZYPADKU W KONTEKŚCIE TEORII NAUKOWYCH}

Pojęcie przypadku jest wieloznaczne, stąd też łatwo jest je dostosować do subiektywnych przekonań. Najczęściej potocznie jest ono rozumiane jako wydarzenie nieoczekiwane, zaskakujące, nieprzewidywane itp. Przykładowo: tuż przede mną z muru upadła cegła, choć była dobrze zabezpieczona; spotykam na ulicy kogoś, kto powinien być aktualnie w innym mieście; nagły i nieoczekiwany powrót do zdrowia ze stanu nie dającego żadnych nadziei. W tego rodzaju sytuacjach wydaje się, że nie powinny się one zdarzyć. Przy takim, również potocznym rozumieniu pojęcia przypadku formułowany jest niekiedy sąd w rodzaju: „to niezwykłe”, „to jest cud”. A przecież pojęcie cudu jest równie wieloznaczne i charakteryzuje się wieloma konotacjami i znaczeniami kontekstowymi. Jednak głębsze analizy pojęcia przypadku prowadzą do nieco innych interpretacji, ważnych w trakcie badań naukowych, a także do prób doprecyzowania pojęcia $\mathrm{cudu}^{4}$. Potocznie cud rozumiany jest jako zjawisko nieprzewidziane,

3 Tamże, p. 48.

4 Zobacz więcej: A. Świeżyński, Cud jako proste działanie ze strony Boga. Filozoficzna propozycja Davida Cornera, Studia Philosophiae Christianae 46(2010)1, 93-124; Tenże, Filozofia cudu. W poszukiwaniu adekwatnej koncepcji zdarzenia cudownego, Warszawa 2012, 41. 
niemożliwe do wyjaśnienia, nadprzyrodzone. Adam Świeżyński, podejmując się analizy zjawisk cudownych, wskazuje na to, że cud określany jest jako zdarzenie ponadnaturalne i spowodowane przez Boga oraz naukowo nie dające się wyjaśnićs. Pierwsze z tych określeń cudu rozważane jest w płaszczyźnie ontologicznej, drugie zaś - epistemologicznej.

Definicja słownikowa przypadku wskazuje, że jest to zdarzenie, dla wystąpienia którego nie istnieje przyczyna, lub dla którego nie umiemy podać przyczyny, a więc którego nie umiemy wytłumaczyć, nie przesądzając, czy jest to niemożność trwała, czy tylko chwilowa ${ }^{6}$.

W literaturze polskiej Kazimierz Kloskowski ${ }^{7}$ podjął próbę klasyfikacji pojęcia przypadku i zjawiska przypadkowego. Najpierw dokonał przeglądu różnych sposobów rozumienia przypadku w odniesieniu do hipotez i teorii dotyczących pochodzenia życia ${ }^{8}$. Okazało się, że w analizowanych teoriach abiogenezy zdarzenia przypadkowe odnoszone były do strukturalno-funkcjonalnej samoorganizacji materii'. Kloskowski ${ }^{10}$, analizując teorie wyjaśniające procesy prowadzące do powstania i ewolucji życia, zwrócił uwagę na różne ujęcia przypadku (od teleologicznego, przez probabilistyczne, po nomologiczne i strukturalne $)^{11}$, a następnie omówił relacje przypadku do przyczyny ${ }^{12}$, do celu ${ }^{13}$ oraz do praw statystycznych i struktural-

5 A. Świeżyński, Filozofia cudu, dz. cyt., 30-55.

6 T. Bigaj, Przypadek, w: Słownik Pojęć Filozoficznych, red. W. Krajewski, Warszawa 1996, 166.

7 K. Kloskowski, Zagadnienie determinizmu ewolucyjnego. Studium biofilozoficzne, Gdańsk 1990, 140; por. także: A. Latawiec, Kilka uwag w sprawie przypadku, w: Wokół biofilozofii Kazimierza Kloskowskiego. Wybrane zagadnienia, red. M. Bała, Pelplin 2004, 84.

8 K. Kloskowski, Przypadek w genezie życia, Studia Philosophiae Christianae 26(1990)2, 163-168.

9 Tamże 167.

10 K. Kloskowski, Przypadek jako czynnik abiogenezy, Studia Philosophiae Christianae 21(1985)2, 39-78.

11 Tamże, 41-49.

12 Tamże, 70-71.

13 Tamże, 71-74. 
nych ${ }^{14}$. Analizując te ujęcia, wspomniany autor wykazał ich dużą różnorodność. Dalsze jego analizy doprowadziły do uchwycenia dwóch istotnych, ogólnych ujęć przypadku. I tak, można zasadniczo wyróżnić dwa rodzaje przypadku: względny i bezwzględny (absolutny). Do pierwszego rodzaju należą te wydarzenia, których przyczyna istnieje w innym układzie odniesienia; zaś do drugiego zdarzenia, które nie znajdują przyczyny w żadnym materialnym układzie odniesienia (inaczej: cuda). Swoje analizy dotyczące wydarzeń przypadkowych Kloskowski przeprowadził w kontekście teorii abiogenezy ${ }^{15}$.

Próbą klasyfikacji rozumienia przypadku zająl się także ks. Grzegorz Bugajak ${ }^{16}$. Jak sam uprzedzi1 ${ }^{17}$, jego koncepcja nie jest ostatecznie ukończona ${ }^{18}$, ale już $\mathrm{w}$ tym kształcie, $\mathrm{w}$ jakim ją sformułował, będzie niezwykle użyteczna dla dalszych analiz i zastosowań. Jej użyteczność wyraża się przede wszystkim w tym, że stanowi ona próbę całościowego przeanalizowania tego pojęcia, używanego w różnych teoriach naukowych.

Koncepcja Bugajaka pomyślana była m.in. jako pewne narzędzie do analiz treści różnych teorii naukowych. Istnieje powszechne przekonanie, że o ile w zjawiskach w skali makro nie napotykamy na większe „niespodzianki”, dotyczące przyczynowo-skutkowego ich wyjaśniania, to w skali mikro takie "niespodzianki” pojawiają się stosunkowo często. Bugajak twierdzi, że analiza kontekstów występowania pojęcia przypadku odnosi się do jego treści, która ma wydźwięk negatywny, ukazując przypadek jako brak czegoś, lub też dotyczy twierdzeń na temat zdarzeń przypadkowych w ich realnym przebiegu

14 Tamże, 74-77.

15 K. Kloskowski, Zagadnienie determinizmu ewolucyjnego, dz. cyt., 140.

16 G. Bugajak, Pojęcie przypadku i jego zastosowanie w analizach teorii naukowych, w: Filozofia przyrody współcześnie, red. M. Kuszyk-Bytniewska, A. Łukasik, Kraków 2010, 235-245.

17 Tamże, 244.

18 Wielokrotnie prowadziliśmy rozmowy z Grzegorzem Bugajakiem nad możliwością rozszerzenia tej autorskiej koncepcji. 
i z uwzględnieniem okoliczności ich wystąpienia. Można więc rozważać treść „przypadkowości” zdarzeń. Wyznaczając układ pojęć prowadzących do określania pojęcia przypadku, Bugajak zauważa możliwość wykorzystania pewnych par kategorii: przyczyna - cel, rzeczywistość - wiedza o rzeczywistości (płaszczyzna ontologiczna i płaszczyzna epistemologiczna) oraz podmiot - przedmiot (sens podmiotowy i sens przedmiotowy). Ponadto proponuje on kolejne rozróżnienie na przypadek absolutny i przypadek względny ${ }^{19}$.

Zgodnie z zaproponowaną typologią omawianego pojęcia, przypadek może być rozumiany jako brak przyczyny lub jako brak celu. W pierwszym typie (jako braku przyczyny) został położony nacisk na faktyczny brak wystąpienia zjawiska poprzedzającego, które skutkowałoby pojawieniem się zdarzenia przypadkowego jako skutku zdarzenia poprzedniego. Ten typ jest wyrazem przypadku ujmowanego ontologicznie. Przypadek ujmowany jako brak przyczyny $\mathrm{w}$ sensie ontologicznym oznacza wydarzenie o absolutnym braku przyczyny. Wydaje się jednak, że tego rodzaju zdarzenie nie jest możliwe. Zdaniem Bugajaka rację dla istnienia takiego zdarzenia można rozpatrywać w filozofii. W literaturze można odnaleźć takie ontologiczne ujęcie przypadku w wyjaśnieniach, pojawiających się w odniesieniu do interpretacji mechaniki kwantowej, w poglądach Boecjusza (u którego chodzi „o rezultat działania zbiegających się przyczyn w rzeczach dziejących się dla jakiejś sprawy"20), czy w stanowisku E. Nagela, który wspomina o zdarzeniu zachodzącym „na przecięciu” dwu niezależnych łańcuchów przyczynowych ${ }^{21}$. To ostatnie ujęcie Bugajak proponuje uzupełnić określeniem „względne”.

W zaproponowanej typologii wydarzeń przypadkowych drugi typ to przypadek rozumiany jako brak przyczyny w sensie

19 G. Bugajak, Pojęcie przypadku i jego zastosowanie w analizach teorii naukowych, dz. cyt., 235.

20 Tamże, 237.

21 Tamże, 238. 
epistemologicznym. Chodzi tu o zdarzenia odnoszone „do wiedzy o związkach przyczynowych, w jakie zdarzenia te wchodzą"22. W literaturze filozoficznej znajdujemy takie wyjaśnienie tego typu zdarzenia, np. u Nagela: „przy braku wiedzy o okolicznościach determinujących jego zajście"23, czy u Spinozy: niepoznane to znaczy przypadkowe. Wspomniane tu interpretacje wystąpienia zjawisk przypadkowych nie wykluczają faktu, że te nieznane w danym momencie przyczyny ich pojawienia się mogą wynikać z braku aktualnej wiedzy (można je wówczas nazwać przypadkami względnymi) lub z nieprzezwyciężalnego braku wiedzy (można je wówczas nazwać przypadkami absolutnymi) ${ }^{24}$.

Jeśli zaś chodzi o pojęcie przypadku rozumiane jako brak celu, to najczęściej spotykamy je w kontekstach potocznych. Bugajak proponuje wprowadzić tu dwa zasadnicze podtypy pojęcia przypadeku: jako przedmiotowy brak celu i jako podmiotowy brak celu. Pierwszy z nich należy rozumieć jako brak ,naturalnego nakierowania”, utożsamianego z prawami przyrody, które sterują zjawiskami przyrodniczymi ${ }^{25}$. A zatem za przypadek jako przedmiotowy brak celu należałoby uznać zdarzenie, które nie jest kierowane prawami przyrody. Jako takie zdarzenie to nie może być przedmiotem badań w ramach nauk przyrodniczych. Jest tak dlatego, że zadaniem tych nauk jest właśnie odkrywanie bądź konstruowanie praw przyrody. Niewystępowanie praw przyrody wyklucza możliwość uprawiania nauk przyrodniczych. Zjawiska przypadkowe w omawianym sensie nie mogą więc być badane naukowo $\mathrm{z}$ powodu braku praw nimi rządzących, aż do czasu ich ustalenia $\mathrm{w}$ świetle szerszej wiedzy. Takie zjawiska można więc, zdaniem Bugajaka, nazwać co najwyżej relatywnymi do aktualnego stanu wiedzy.

22 Tamże.

23 Tamże.

24 Tamże.

25 Tamże, 239. 
Drugi podtyp pojęcia przypadku wiązany z celem rozumiany jest jako podmiotowy brak celu ${ }^{26}$. Pojęcie przypadku można bowiem łączyć z intencją czy świadomym wyborem celów. Oznacza to, że przyjmuje się istnienie jakiegoś podmiotu, świadomego swoich wyborów lub działań. W tym kontekście przypadek jako podmiotowy brak celu to zdarzenie niespodziewane, nieplanowane. Takie zdarzenie należy interpretować jako względne, gdyż nieplanowane czy nieoczekiwane wydarzenie nie dotyczy podmiotu, dokonującego wyborów i planującego działania. Są to działania konkretnego podmiotu, stąd ich skutki nie są przypadkowe. Skutki (zdarzenia przypadkowe) pojawią się, gdy akty podjęte są świadomie, ale intencje poznającego podmiotu rozmijają się $\mathrm{z}$ osiągniętymi rezultatami. W tej sytuacji można też mówić o zaistnieniu przypadku. Przypadek jako podmiotowy brak celu jawi się więc jako zdarzenie, które nie jest skutkiem świadomej działalności podmiotu oraz jako zdarzenie, będące efektem podjętej działalności podmiotu, lecz nakierowane na inny niż osiągnięty cel. W obu typach mamy do czynienia ze względnym charakterem przypadku. Bugajak proponuje, by nazwać je „mianem przypadku jako podmiotowego względnego braku celu"27.

W tej kategorii zdarzeń przypadkowych należy także uwzględnić ich charakter absolutny. Przypadkiem jako podmiotowym absolutnym brakiem celu ${ }^{28}$ byłoby zdarzenie, w którym nie istniałby żaden podmiot aktów woli czy poznania, czyli zdarzenie, co do którego byłby absolutny brak uświadomionych celów czy planów. Taka sytuacja nie podlega badaniom naukowym.

W odniesieniu do rozumienia przypadku jako podmiotowego braku celu należy jeszcze rozważyć aspekt ontologiczny i aspekt epistemologiczny. I tak, w aspekcie ontologicznym ,orzekanie o przypadku dotyczy zaprzeczenia istnienia podmiotu planującego czy

26 Tamże, 242.

27 Tamże, 243.

28 Tamże. 


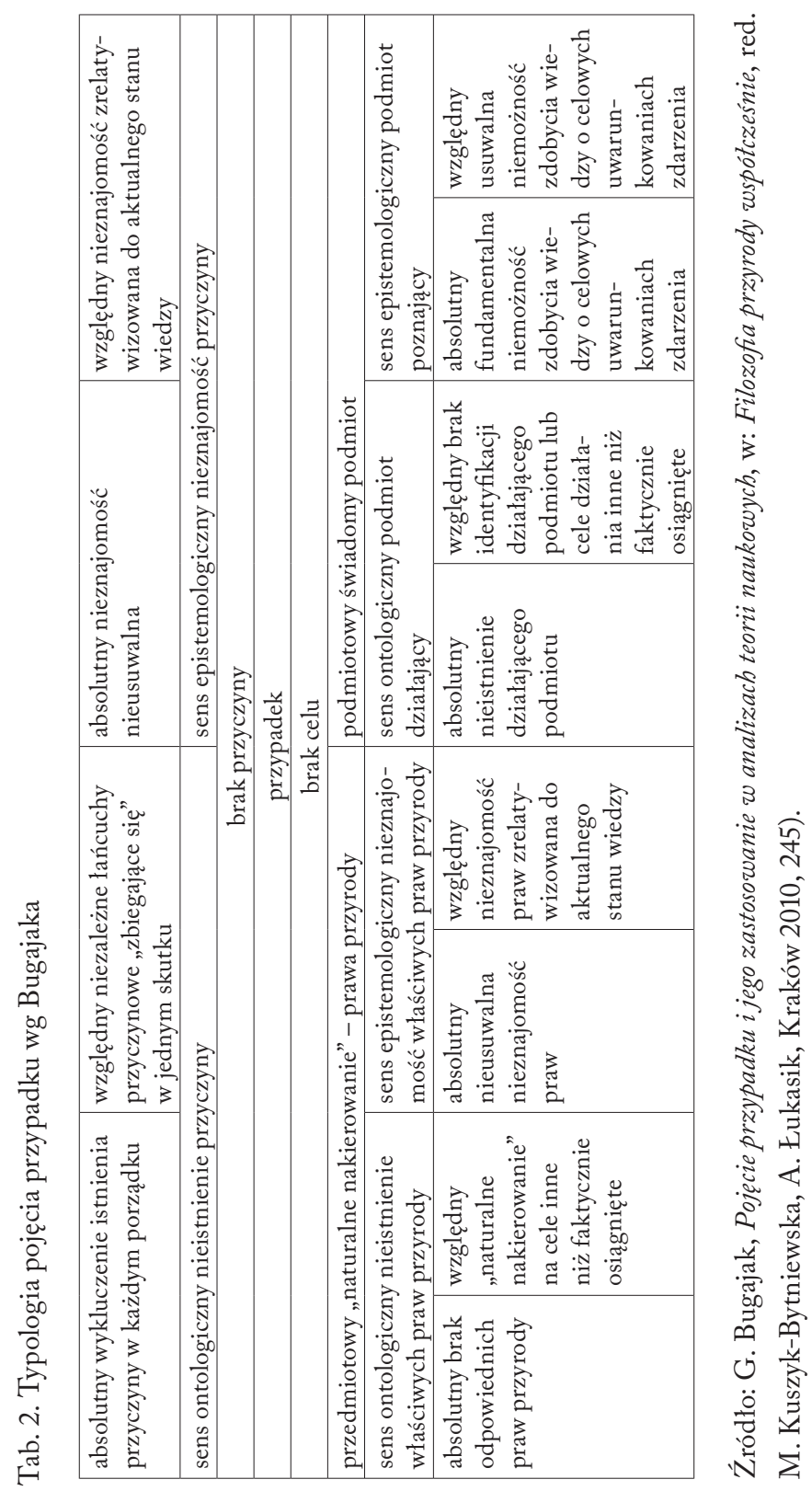


sprawiającego pewien skutek (w wersji absolutnej) lub twierdzenia, że skutek ów nie jest rezultatem świadomego działania jakiegoś konkretnego podmiotu (w wersji względnej). W sytuacji zaś, gdy jakiś skutek nie jest przewidziany przez kogoś (sens względny) lub nie może być przewidziany przez nikogo (sens absolutny), mamy do czynienia z przypadkiem jako podmiotowym brakiem celu w sensie epistemologicznym" 29 .

Już pobieżna analiza schematu dotyczącego pojęcia przypadku autorstwa Bugajaka pozwala zauważyć, że w naukach przyrodniczych należy pominąć wszystkie ujęcia o charakterze absolutnym. Wypracowana klasyfikacja, jak sam Bugajak wskazuje, ma być pomocna przy „precyzyjnym formułowaniu i odczytywaniu stanowisk zajmowanych w wielu filozoficznych dyskusjach, zwłaszcza tych, które dotyczą interpretacji osiągnięć nauk przyrodniczych"30. Aby wykazać użyteczność koncepcji Bugajaka, będziemy w dalszej części tekstu analizować zjawiska przypadkowe, rodzące dylematy w pracach badawczych ekologów, a zachodzące zarówno w przyrodzie, jak i w działaniach dotyczących ochrony przyrody. Przyjęcie w poniższym artykule perspektywy nauk przyrodniczych skutkować będzie pewnym ograniczeniem koncepcji Bugajaka i skupieniu się na przypadkach w ujęciu względnym. Poniżej przedstawiony jest schemat po uwzględnieniu przyjętego założenia.

29 Tamże, 244.

30 Tamże, 245. 
Tab. 2. Typologia pojęcia przypadku w naukach przyrodniczych

\begin{tabular}{|c|c|c|c|}
\hline \multicolumn{2}{|c|}{$\begin{array}{l}\text { sens ontologiczny (nieistnienie przyczyny) } \\
\text { niezależne łańcuchy przyczynowe „zbie- } \\
\text { gające się” w jednym skutku - np. procesy } \\
\text { ewolucyjne }\end{array}$} & \multicolumn{2}{|c|}{$\begin{array}{l}\text { sens epistemologiczny (nieznajomość przy- } \\
\text { czyny)nieznajomość zrelatywizowana do } \\
\text { aktualnego stanu wiedzy }\end{array}$} \\
\hline \multicolumn{4}{|c|}{ brak przyczyny } \\
\hline \multicolumn{4}{|c|}{ przypadek } \\
\hline \multicolumn{4}{|c|}{ brak celu } \\
\hline \multicolumn{2}{|c|}{$\begin{array}{l}\text { przedmiotowy „naturalne nakierowanie” } \\
\text { - prawa przyrodynp. czynniki ewolucyjne - } \\
\text { mutacje, izolacje }\end{array}$} & \multicolumn{2}{|c|}{ podmiotowy świadomy podmiot } \\
\hline $\begin{array}{l}\text { sens ontologiczny } \\
\text { (nieistnienie właści- } \\
\text { wych praw przyrody) } \\
\text { - „naturalne nakiero- } \\
\text { wanie” na cele inne } \\
\text { niż faktycznie } \\
\text { osiągnięte }\end{array}$ & $\begin{array}{l}\text { sens epistemolo- } \\
\text { giczny (nieznajomość } \\
\text { właściwych praw } \\
\text { przyrody) - nie- } \\
\text { znajomość praw } \\
\text { zrelatywizowana do } \\
\text { aktualnego stanu } \\
\text { wiedzy }\end{array}$ & $\begin{array}{l}\text { sens ontologiczny } \\
\text { (podmiot działający) } \\
\text { - brak identyfi- } \\
\text { kacji działającego } \\
\text { podmiotu lub cele } \\
\text { działania inne niż } \\
\text { faktycznie osiągnięte }\end{array}$ & $\begin{array}{l}\text { sens epistemolo- } \\
\text { giczny (podmiot } \\
\text { poznający) - } \\
\text { usuwalna nie- } \\
\text { możność zdobycia } \\
\text { wiedzy o celowych } \\
\text { uwarunkowaniach } \\
\text { zdarzenia }\end{array}$ \\
\hline
\end{tabular}

Opracowanie własne na podstawie: G. Bugajak, Pojęcie przypadku i jego zastosowanie w analizach teorii naukowych, w: Filozofia przyrody wspótcześnie, red. M. Kuszyk-Bytniewska, A. Łukasik, Kraków 2010, 245).

\section{PRZYPADEK A NAUKI PRZYRODNICZE}

Wydarzenia w świecie przyrody powszechnie poznaje się dzięki zmysłom. Obserwacje te pozwalają na sformułowanie wniosku, że świat przyrody jest uporządkowany, dobrze zorganizowany. Można przyjąć, że porządek i organizacja w świecie przyrody przejawiają się zarówno w strukturze organizmów, jak i w ich funkcjonowaniu. Według Teresy Ścibor-Rylskiej organizację tę można rozumieć jako „zespolenie w całość różnorodnych strukturalnie i funkcjonalnie elementów, współdziałających ze sobą w sposób skoordynowany, harmonijny i ekonomiczny dla osiągnięcia zaplanowanych celów"31.

31 T. Ścibor-Rylska, Tajemnice uorganizowania żywej komórki, Warszawa 1986, 59. 
Wydaje się, że zarówno organizacja, jak i porządek mają celowy charakter. Za ten porządek organizacyjny w strukturach i funkcjach odpowiada informacja. Jest ona czynnikiem sterującym procesami strukturalnymi i funkcjonalnymi. W ożywionej przyrodzie występują różne typy informacji (biologicznej), przenoszonej za pomocą odpowiednich rodzajów nośników. Stąd też w procesie poznawania zmysłowego jawi się nam obraz zdarzeń celowych, uporządkowanych, dobrze zorganizowanych. Mają one swoje uzasadnienie w prawach przyrody, a także w przekonaniu filozofów, że każda zmiana, każde zjawisko wywołują oczekiwane zmiany czy inne zjawiska. Według filozofów oznacza to zgodność z zasadą, że każde zjawisko zawsze i z konieczności wywołuje ściśle określone zjawisko, czyli ta sama przyczyna wywołuje ten sam skutek. W makroświecie obraz ten postrzegany jest jako zdeterminowanie, w którym nie ma miejsca na zjawiska nieprzewidziane, przypadkowe. $\mathrm{W}$ mikroświecie nie obserwujemy takiej prostej zależności. A właśnie w tej skali zjawiska są wyjaśniane w świetle teorii kwantowej. Oznacza to, że mikroświat charakteryzuje się indeterminizmem. Nie oznacza to, że w tej sytuacji mamy pełną dowolność przebiegu zdarzeń, lecz że zachowane jest jakieś prawdopodobieństwo ich występowania.

Jak zauważa Anna Lemańska, przedmiotem badań nauk przyrodniczych są wyłącznie zjawiska, czyli to, co można zaobserwować (bezpośrednio lub pośrednio). Możemy zatem przewidywać zdarzenia, opisywać świat, wyjaśniać zachodzące w przyrodzie zjawiska. Jednak metoda nauk przyrodniczych ma swoje ograniczenia, gdyż nie pozwala na wyjście poza to, co można zaobserwować32. „W obszarze nauk przyrodniczych w szczególności nie można rozstrzygać o istnieniu bądź nieistnieniu rzeczywistości pozazjawiskowej, rzeczywistości transcendentnej względem świata materialnego. Zadaniem filozofa jest jednak próba dotarcia do istoty rzeczywistości ukrytej

32 Zob. A. Lemańska, Filozofia przyrody a wyniki nauk przyrodniczych, Studia Philosophiae Christianae 43(2007)1, 115-123. 
poza zjawiskami. To, co w filozofii jest określane mianem istoty, nie jest możliwe do zaobserwowania"33.

Zdarzenia przypadkowe możemy dostrzec także w zjawiskach przyrodniczych, badanych przez nauki przyrodnicze, zajmujące się ochroną przyrody. Przykładem mogą być badania podejmowane nad różnorodnością biologiczną na wszystkich jej poziomach (genetycznym, gatunkowym, ekosystemowym). Janusz Uchmański zwraca uwagę na pytania, na które trudno jest obecnie znaleźć odpowiedź: (1) jakie są przyczyny tego, że różnorodność biologiczna trwa, a po każdym zdarzeniu powodującym jej obniżenie, życie na Ziemi powraca w jeszcze większej obfitości i różnorodności?; (2) jeśli nie dobór naturalny, to co zapewnia trwałość różnorodności biologicznej?34. Okazuje się więc często, że nie znamy przyczyny obserwowanych zjawisk.

Zagadnienie przypadku możemy zaobserwować w conservation biology, zaproponowanej przez Michaela E. Soulé w 1985 roku. Jak sam autor stwierdził, jest to „dyscyplina kryzysowa”, gdyż biolodzy zajmujący się ochroną przyrody, muszą podejmować decyzje nie mając pełnej wiedzy co do ich skutków ${ }^{35}$. Jest to uwarunkowane tym, że propozycja tej nauki jest odpowiedzią na dostrzeżony kryzys ekologiczny i szybkie zmiany zachodzące w środowisku naturalnym. Dlatego, jak przekonuje Soulé, nie ma czasu na czekanie na sprawdzone rozwiązania. Należy zatem działać, licząc się zarówno z niepowodzeniami przy ochronie bioróżnorodności, jak i z występującymi zdarzeniami przypadkowymi. Ma to być cena za zmniejszenie tempa wymierania gatunków i utraty siedlisk. Takie dyscypliny kryzysowe mają charakter interdyscyplinarny, gdyż obejmują wyniki badań nauk ścisłych i humanistycznych. Dzięki tej interdyscyplinarności

33 Tamże, 120.

34 Por. J. Uchmański, Ekologia oczami nie ekologa, Studia Ecologiae et Bioethicae 15(2017)2, 27-39.

35 M.E. Soulé, What Is Conservation Biology?, BioScience 35(1985)11, 727-734. 
poszerzają się także możliwości badawcze, zaczerpnięte $\mathrm{z}$ obu dyscyplin. Wymieniona nauka przyrodnicza będzie charakteryzowała się tym, że w jej obszarze napotykać będziemy przypadek rozumiany jako podmiotowy brak celu (względny).

\section{DYLEMAT POZNAWCZY JAKO SKUTEK ZDARZEŃ PRZYPADKOWYCH}

Jak wskazuje Michał Heller, przypadek jest nieusuwalnym elementem wszechświata: „(...) przypadek nie jest jakąś destrukcyjną siłą, która niszczy, lub przynajmniej narusza, strukturę Wszechświata zakodowaną w prawach przyrody. (...) Co więcej, przypadki nie są wyłomem w matematycznym porządku Wszechświata, same mają charakter matematyczny i, jako takie, są istotnym aspektem "matematyczności świata "36. Podobnie twierdzi Lemańska, pisząc, że „zachodzenie zdarzeń przypadkowych nie oznacza zatem tego, że przyroda jest chaosem, nie przeczy też zasadzie przyczynowości" ${ }^{37}$. Ponadto „ich zajście jest spowodowane zetknięciem się niezależnych od siebie ciągów przyczynowych, które z reguły są ściśle zdeterminowane. (...) Wydaje się bowiem, że struktury biologiczne powstały na skutek działania tego rodzaju przypadku. Nawet jednak te zdarzenia, które są przypadkowe w sensie bezwzględnym (nie mają swej przyczyny w żadnym układzie odniesienia), podlegają prawom rachunku prawdopodobieństwa"38.

Warto podkreślić $\mathrm{w}$ tym miejscu, że zdobyta przez konkretnego człowieka wiedza o zjawiskach w przyrodzie ma charakter fragmentaryczny. Jest ona bowiem ,zakresowo ograniczona do wycinka rzeczywistości i to ujętej jeszcze z określonej strony, w zależności od typów aktów poznawczych, jakimi się posłużył. Od tego natomiast,

36 M. Heller, Konieczność i przypadek w ewolucji Wszechświata, Studia Philosophiae Christianae 46(2010)1, 24.

37 A. Lemańska, Kilka uwag o zdeterminowaniu przyrody, Studia Philosophiae Christianae 39(2003)2, 235.

38 Tamże. 
w jaki sposób owe akty spełnił, zależy jakość uzyskanej wiedzy. $Z$ tej racji możemy mówić o stopniach wiedzy, nigdy jednak nie możemy zasadnie mówić o stopniowaniu prawdy"39.

W praktyce ochrony środowiska przyrodniczego spotykamy się z dylematami o charakterze poznawczym i decyzyjnym. Często przyjmuje się, że dylemat dotyczy dokonania wyboru jednej z równoważnych możliwości o tej samej wadze, przy czym wybór jednej z nich oznacza utratę rozwiązania alternatywnego. Stąd skutki tego wyboru ujawniają się z biegiem czasu. Jedna grupa dylematów wynika $z$ naszej niewiedzy przy podejmowaniu decyzji, co do działania na rzecz przyrody. W konsekwencji oznaczać będzie nieznajomość skutków podjętego działania. Na przykład decyzja, dotycząca wyboru przedmiotu ochrony na danym terenie: czy proces przyrodniczy, czy stan przyrody, który jest nam obecnie znany. Ochrona jednego aspektu wyklucza drugi. Proces przyrodniczy jest dynamiczny i zmienny, a więc przyroda ma podlegać zmianom. Oznacza to możliwość dopuszczenia do utraty chronionych elementów. W drugim przypadku ochrona aktualnej postaci przyrody może być postrzegana jako próba zakonserwowania pewnego stanu przyrody i niedopuszczania do przebiegu wybranych naturalnych procesów.

Inaczej rzecz ujmując, możemy mówić o dylematach w sytuacji wystąpienia nieoczekiwanych skutków działalności człowieka. $\mathrm{Pu}-$ stynia Błędowska jest dobrym tego przykładem. Obecny wygląd tego miejsca jest efektem znaczącej degradacji całego terenu. Dziś jednak przyrodnicy chronią przypadkowo wykształcone siedlisko i nasza działalność ma na celu niedopuszczenie do przywrócenia stanu sprzed naszej pierwszej, znacząco negatywnej ingerencji ${ }^{40}$. Można więc powiedzieć, że cenione walory tego obszaru są efektem zdarzeń przypadkowych.

39 J. Krokos, W poszukiwaniu istoty prawdy, Studia Philosophiae Christianae 34(1998)1, 37.

40 M. Latawiec, Rozpoznawanie granic ingerencji człowieka w środowisko przyrodnicze, Studia Ecologiae et Bioethicae 14(2016)1, 85. 
Niektóre zjawiska przypadkowe można z perspektywy czasu wyjaśnić za pomocą nauk przyrodniczych. Taki przykład odnajdujemy na terenie Yellowstone, gdzie wskutek pojawienia się nowego gatunku ryby w jeziorze populacja jeleni zaczęła się starzeć. Zjawisko to można traktować jako przypadkowe. Otóż ryba palia jeziorowa (Salvelinus namaycush) ${ }^{41}$ zaczęła wypierać $\mathrm{z}$ naturalnych stanowisk łososia Clarka (Oncorbynchus clarkii). W konsekwencji tego procesu zmniejszyła się liczebność łososi składających ikrę w niewielkich strumykach wokół jeziora, zaś palia swą ikrę składa na dnie jeziora, nie wpływając do strumieni. To z kolei wpłynęło na dietę niedźwiedzi grizzly (Ursus arctos horribilis). Te ostatnie po ograniczeniu liczebności łososi w potokach wiosną zaczęły polować na młode jelenie (Cervus elaphus ${ }^{42}$. I właśnie te polowania na młode osobniki przyspieszyły efekt starzenia się populacji jeleni. Zatem w początkowej sytuacji pojawienie się efektu starzenia wśród populacji jeleni miało w sensie poznawczym charakter przypadkowy, dopóki nie została poszerzona wiedza naukowców. $Z$ kolei wiedza ta eliminuje część potencjalnych (i rzeczywistych, wcześniejszych) dylematów, wynikających z wyboru strategii ochrony omawianego ekosystemu.

Rozwój badań ekologicznych przyczynia się do wyjaśniania występowania zjawisk przypadkowych. Nie zawsze jednak otrzymywany jest ich pełny obraz i nie zawsze jeszcze uzyskujemy o nich pełną wiedzę. Przykładem takiej sytuacji mogą być prace nad reintrodukcją motyla - modraszka ariona (Maculinea arion). Mimo poznania gatunków roślin żywicielskich i mrówek wpływających na sukces jego populacji w każdej fazie cyklu życiowego motyla, nadal część pytań pozostaje bez odpowiedzi. „Nie wiadomo właściwie, na czym

41 Gatunek ten na innych stanowiskach sam jest zagrożony.

42 A.D. Middleton, T.A. Morrison, J.K. Fortin, C.T. Robbins, K.M. Proffitt, P.J. White, D.E. McWhirter, T.M. Koel, D.G. Brimeyer, W.S. Fairbanks, M.J. Kauffman. Grizzly bear predation links the loss of native trout to the demography of migratory elk in Yellowstone, Proceedings of the Royal Society B: Biological Sciences 280(2013)1763, doi: 10.1098/ rspb.2013.0870. 
polega mechanizm adopcji przez mrówki. Długi, kilkudziesięciominutowy rytuał sugeruje, że w tym czasie gąsienica nabiera od robotnic pewnych cech chemicznych - swoistego kamuflażu. Nie wyjaśnia to jednak wysokiej specyficzności w stosunku do gospodarza"43.

W swojej koncepcji przypadku Bugajak wyraźnie podkreślił, że istnieje wiele sposobów rozumienia zarówno pojęcia przypadku, jak i wydarzenia przypadkowego. Należy zaznaczyć, że ocena, czy zauważone wydarzenie ma charakter przypadkowy czy nie, jest możliwa dopiero po jego zaistnieniu. Inaczej jest, gdy mamy ocenić wydarzenia w sytuacji dylematu poznawczego. Dylemat to rozterka przed podjęciem działania lub rozterka po ujawnieniu wydarzenia lub ciągu wydarzeń przypadkowych. Wydaje się, że dylematy najpierw pojawiają się w umysłach decydentów przed podjęciem działania na rzecz ochrony przyrody, ale czasami są one rozpoznawane dopiero po podjęciu jakiejś ingerencji człowieka w przyrodę. Formułowane jest wówczas pytanie: jak możliwe jest pojawienie się tak nieoczekiwanego, nieprzewidzianego skutku? Być może jest to skutek nieumiejętnego poznania rzeczywistości przyrodniczej i fałszywego rozpoznania reguł w niej panujących. Przytoczona koncepcja przypadku Bugajaka pozwala lepiej zrozumieć istotę takiego dylematu i źródło jego pochodzenia.

\section{ZAKOŃCZENIE}

Wykazano, że koncepcja przypadku G. Bugajaka jest przydatna $\mathrm{w}$ identyfikowaniu zjawisk przypadkowych $\mathrm{w}$ obszarze ochrony przyrody. Zjawiska te wywołują wśród ekologów rozmaite dylematy poznawcze. W sytuacji konieczności podejmowania decyzji dotyczących zarządzania przyrodą, istotne jest ustalenie źródła, przyczyn

43 M. Sielezniew, A.M. Stankiewicz, Historia modraszka ariona Maculinea arion L., czyli jak motyl wszedl do kanonow ekologii i ochrony przyrody, Wiadomości Ekologiczne $50(2004) 3,163$. 
i sposobów ich zaistnienia. Podkreślono, które ujęcie przypadku jest użyteczne w praktycznej ochronie przyrody. Zatem spośród zaproponowanych typów przypadku w naukach przyrodniczych odnajdujemy pojawianie się zjawisk przypadkowych, wynikających z nieznajomości ich przyczyny, a więc przypadku w sensie epistemologicznym. Mogą one wystąpić również na skutek braku celu w ujęciu podmiotowym względnym.

Okazuje się też, że dylematy w ochronie przyrody wynikają z nieznajomości przyczyny zaistnienia zjawisk przypadkowych. Przy wstępnym przyjęciu, że dylemat poznawczy to pewien rodzaj rozterki, możemy uznać, iż powstaje on już w chwili dokonywania wyboru działania i ustalania konsekwencji tych wyborów. Ten rodzaj dylematu jest skutkiem ułomności ludzkiego poznania. Działalność ekologów powinna być związana ze znajomością celów ich działania. Stąd pojawienie się zjawiska przypadkowego w efekcie podjętych działań celowych wynikać może $\mathrm{z}$ nieprawidłowego rozpoznania celu lub z niedostatecznej wiedzy o skutkach planowanej aktywności.

Przyroda ożywiona mimo funkcjonowania według poznanych praw, jest bardziej skomplikowana i tajemnicza niż się to powszechnie uważa - różnego rodzaju relacje, zachodzące między organizmami i ich środowiskiem, są przyczyną pojawiania się zjawisk przypadkowych. Naszym celem było wskazanie użyteczności koncepcji przypadku Bugajaka oraz uchwycenie relacji zachodzących między przypadkiem wyróżnionym w zaproponowanej przez niego typologii i dylematem poznawczym, poprzedzającym działania w zakresie ochrony środowiska.

\section{BIBLIOGRAFIA}

Bigaj T., Przypadek, w: Stownik Pojęć Filozoficznych, red., W. Krajewski, Warszawa 1996, 166.

Bugajak G., „Rozum a wiara” - problem separacji dyscyplin, Studia Philosophiae Christianae 43(2007)2, 132-148. 
Bugajak G., Pojęcie przypadku i jego zastosowanie w analizach teorii naukowych, w: Filozofia przyrody wspótcześnie, red. M. Kuszyk-Bytniewska, A. Łukasik, Wydawnictwo Universitas, Kraków 2010, 235-245.

Bugajak G., Poczatek świata w nauce i religii. W poszukiwaniu możliwości syntezy, Studia Philosophiae Christianae 32(1996)2, 135-147.

Heller M., Bóg i geometria. Gdy przestrzeń byta Bogiem, Copernicus Center Press, Kraków 2016.

Heller M., Konieczność i przypadek w erwolucji Wszechświata, Studia Philosophiae Christianae 46(2010)1, 17-24.

Jan Paweł II, Fides et ratio, Rzym 1998.

Kloskowski K., Przypadek jako czynnik abiogenezy, Studia Philosophiae Christianae 21(1985) 2, 39-78.

Kloskowski K., Przypadek w genezie życia, Studia Philosophiae Christianae, 26(1990)2, 163-168.

Kloskowski K., Zagadnienie determinizmu ewolucyjnego. Studium biofilozoficzne, Wydawnictwo „Stella Maris”, Gdańsk 1990.

Krajewski W. (red.), Stownik Pojęć Filozoficznych, Wydawnictwo Naukowe Scholar, Warszawa 1996.

Krokos J., W poszukiwaniu istoty prawdy, Studia Philosophiae Christianae 34(1998)1, 25-41.

Latawiec A., Kilka uwag w sprawie przypadku, w: Wokót biofilozofii Kazimierza Kloskowskiego. Wybrane zagadnienia, red. M. Bała, Wydawnictwo Bernardinum, Pelplin 2004, 81-86.

Latawiec M., Rozpoznawanie granic ingerencji człowieka w środowisko przyrodnicze, Studia Ecologiae et Bioethicae 14(2016)1, 77-97.

Lemańska A., Filozofia przyrody a wyniki nauk przyrodniczych, Studia Philosophiae Christianae 43(2007)1, 115-123.

Lemańska A., Kilka uwag o zdeterminowaniu przyrody, Studia Philosophiae Christianae 39(2003)2, 221-235.

Middleton A.D., Morrison T.A., Fortin J.K., Robbins C.T., Proffitt K.M., White P.J., McWhirter D.E., Koel T.M., Brimeyer D.G., Fairbanks W.S., Kauffman M.J., Grizzly bear predation links the loss of native trout to the demography of migratory elk in Yellowstone, Proceedings of the Royal Society B: Biological Sciences, 280(2013)1763, doi: 10.1098/rspb.2013.0870.

Sielezniew M., Stankiewicz A.M., Historia modraszka ariona Maculinea arion L., czyli jak motyl wszedt do kanonów ekologii i ochrony przyrody, Wiadomości Ekologiczne 50(2004)3, 149-169.

Soulé M.E., What Is Conservation Biology?, BioScience, 35(1985)11, 727-734. 
Ścibor-Rylska T., Tajemnice uorganizowania żywej komórki, PAX, Warszawa 1986. Świeżyński A., Cud jako proste dziatanie ze strony Boga. Filozoficzna propozycja Davida Cornera, Studia Philosophiae Christianae 46 (2010)1, 93-124.

Świeżyński A., Filozofia cudu: w poszukiwaniu adekwatnej koncepcji zdarzenia cudownego, Wydawnictwo UKSW, Warszawa 2012.

Uchmański J., Ekologia oczami nie ekologa, Studia Ecologiae et Bioethicae 15(2017)2, 27-39.

\section{THE USEFULNESS OF GRZEGORZ BUGAJAK'S CHANCE CONCEPT IN THE NATURAL} SCIENCES

Abstract. Nature is known through empirical methods. The development of a scientific
methodology enables us to reveal the secrets of nature. Hypothesis and theories are
formulated in order to explain phenomena. However, in this ordered world there are also
events that occur randomly. Within this framework, Grzegorz Bugajak's concept of chance
will be applied to show its usefulness in the field of environmental protection. By refer-
ring to specific examples, we will discuss the circumstances of the occurrence of random
phenomena in nature that create dilemmas for naturalists. Our aim is to single out an
interpretation of Bugajak's concept of chance that can be usefully employed by ecologists.

Keywords: Grzegorz Bugajak; chance; nature; knowledge dilemma; environmental protection

Michał Latawiec

Uniwersytet Kardynała Stefana Wyszyńskiego w Warszawie, Instytut Filozofii

(Cardinal Stefan Wyszyński University in Warsaw, Institute of Philosophy, Poland)

ORCID: https://orcid.org/0000-0001-8803-4202

m.latawiec@uksw.edu.pl

Anna Latawiec

Uniwersytet Kardynała Stefana Wyszyńskiego w Warszawie, Instytut Filozofii

(Cardinal Stefan Wyszyński University in Warsaw, Institute of Philosophy, Poland)

ORCID: https://orcid.org/0000-0002-0769-7328

a.latawiec@uksw.edu.pl

DOI: 10.21697/spch.2020.56.4.05 